УДК 338.431 .2

\author{
Стойка В.о. \\ кандидат економічних наук \\ кафедра економічної теорії та права \\ E-mail: vet_ua2@mail.ru \\ Уманський державний педагогічний університет імені Павла Тичини \\ вул. Садова, 2, м. Умань, Черкаська обл., Україна, 20300
}

\title{
СОЦІАЛЬНА ВІДПОВІДАЛЬНІСТЬ БІЗНЕСУ - ВАЖЛИВА СКЛАДОВА АГРОПРОДОВОЛЬЧОГО РИНКУ
}

\begin{abstract}
У статті розглянуто окремі аспекти формування соціальної відповідальності підприємств агропродовольчої сфери, їх участі у соціальному розвитку міст, регіонів та країни в цілому, визначено умови для розширення практики соціальної відповідальності бізнесу. Запропоновано схему реалізації системи соціальної відповідальності бізнесу в агропродовольчій сфері.

Ключові слова: агропродовольча сфера, соціальна відповідальність бізнесу, екологічна відповідальність, еколого-економічна безпека, конкурентні переваги, сталий розвиток, стратегія.
\end{abstract}

Постановка проблеми та її зв'язок з важливими науковими та практичними завданнями. Термін «соціальна відповідальність бізнесу» почали використовувати у 50-і роки XX століття, його поява знаменувалася розвитком корпоративної власності та збільшенням впливу корпорацій на світовий розвиток. Вважається, що поштовхом до підвищення актуальності проблеми соціальної відповідальності бізнесу стала міжнародна конференція із стійкого розвитку, що відбулася в 1992 році в Ріо-де-Жанейро, де були зафіксовані нові вимоги з боку світової спільноти до корпорацій з підвищення їх соціальної відповідальності і визначена соціальна роль бізнесу на міжнародному рівні. Цього ж року Г. Беккер (США) став лауреатом Нобелівської премії за розвиток економічного аналізу тих сфер діяльності людини, які досі входили до компетенції соціальних наук [1, с. 53].

Теорія соціальної відповідальності бізнесу вже тривалий період вивчається представниками українського бізнесу.

В сучасних умовах господарювання соціальна відповідальність бізнесу є складовою його корпоративної стратегії. Реалізація принципу соціальної відповідальності пов'язана 3 публічно-правовим регулюванням фондів грошових коштів комерційних організацій, тобто правове регулювання відносин щодо розподілу прибутку повинно забезпечувати використання частини прибутку комерційних організацій з метою здійснення соціальної функції і часткового фінансування програм із вирішення соціальних проблем суспільства.

Аналіз останніх публікацій по проблемі. Питання становлення соціальної відповідальності бізнесу досліджують такі відомі вчені, як: Беккер Г., Белявська К.,
Божкова В., Власова Т., Ворончак I., Грановська I., Сагер Л., Халда Н. та інші.

Проте, враховуючи стрімкий розвиток суспільства, проблеми реалізації системи соціальної відповідальності бізнесу в агропродовольчій сфері потребують подальшого дослідження.

Формулювання цілей дослідження. Метою даної статті є дослідження агропродовольчої сфери в контексті реалізації системи соціальної відповідальності бізнесу.

Виклад основних результатів та їх обгрунтування. Соціальна відповідальність бізнесу - це концепція, що стимулює підприємства брати на себе зобов'язання з реалізації значущих внутрішніх і зовнішніх соціальних програм, результати яких сприяють розвитку підприємства, підвищуючи його конкурентні переваги у довгостроковій перспективі, поліпшенню його репутації та іміджу як соціально відповідального суб'єкта, а також розвитку суспільства в соціальній, економічній та екологічній сферах [1, с. 53].

Підходи вчених, що досліджують еволюцію соціальної відповідальності бізнесу у суспільстві різняться.

М. Фрідмен звертає увагу на те, що капіталістична економічна система визнає лише одну соціальну відповідальність ділового світу - використовувати надані ресурси і займатися діяльністю, пов'язаною з максимізацією прибутків, за умов дотримання правил гри вільної конкуренції [12, с. 33]. Дана теорія отримала назву «Теорія корпоративного егоїзму».

Протилежна їй - «Теорія корпоративного альтруїзму», яка базується на рекомендаціях Комітету із економічного розвитку. У рекомендаціях йдеться про те, що корпорації зобов’язані вносити значний внесок до поліпшення якості американського життя [3, с. 87]. 
Існує ще одна теорія, яка має назву «Теорія розумного егоїзму». Основні її положення побудовані на тому, що соціально відповідальний бізнес залежить від масштабу відповідальності. Отже, беручи на себе в чомусь функції держави, він тим самим придбав право впливати в окремих питаннях на іï політику, причому на самих різних рівнях [6].

Проте, описані вище теорії підтримують позицію стосовно того, що соціальна відповідальність - це відповідальність компанії перед постачальниками, найманими працівниками, споживачами і організаціями, з якими вони стикаються в процесі виробництва, розподілу, обміну та споживання та перед суспільством в цілому.

Соціальна відповідальність бізнесу залежить від його масштабу. Завдання малого підприємництва полягає у створенні гідно оплачуваних робочих місць, формуванні середнього класу, школи ініціативи. Завдання середнього бізнесу полягає у забезпеченні розвитку міста, області чи регіону. Великий бізнес, який створює робочі місця сотням тисяч людей, відповідальний як за їх матеріальне благополуччя, умови їх розвитку, так і за розвиток великих регіонів і країни в цілому.

Основою соціальної відповідальності бізнесу $є$ оцінка комерційної діяльності компанії з метою визначення ï загального впливу на суспільство. До сфери соціальної відповідальності компанії відносять соціальну відповідальність перед працівниками, охорону навколишнього середовища, поведінку на ринку, залучення до життя громадськості [8].

До соціальної відповідальності бізнесу необхідно відносити також: своєчасну сплату податків, виплату заробітної плати, надання нових робочих місць; забезпечення працівників адекватними умовами не тільки роботи, але й життя: підвищення рівня кваліфікації працівників, профілактичне лікування, будівництво житла, розвиток соціальної сфери; благодійну діяльність тощо.

В останні два десятиліття як альтернатива стереотипам споживчого суспільства стала формуватися концепція стійкого розвитку.

Під стійким розвитком в сучасних умовах розуміють таку модель соціально-економічного розвитку, при якій досягається задоволення життєвих потреб нинішнього покоління без позбавлення майбутніх поколінь таких можливостей унаслідок вичерпання природних ресурсів і деградації навколишнього природного середовища [4].

Безмежно зростаючі потреби суспільства у товарах сільськогосподарського походження стимулюють об’єднувати зусилля великої кількості галузей та сфер економіки, які працюють на задоволення потреб споживача. Саме на цій основі, на думку Катан Л.І., і виникла об'єктивна необхідність виділення поняття аграрний бізнес, основна мета якого - забезпечити кінцевого споживача продуктами харчування у відповідності до його потреб та вимог, та головної його складової - агропродовольчої системи, яка об'єднує виробництво, переробку, а також продовольчий ринок [4].

Юрчишин В.В. вважає, що депресивний стан сільських територій зумовлений сутнісною, правовою, організаційною недосконалістю сучасних аграрних трансформацій, у яких загалом не врахована або системно деформована її визначальна складова - соціальна [11, с. 45].

Важливість такого підходу пов'язана з необхідністю, по-перше, реалізації принципів сталого розвитку на всіх рівнях, у тому числі на агропродовольчому ринку; по-друге, урахування загальносвітових тенденцій посилення впливу екологічного менеджменту і маркетингу у виробництві і, як наслідок, формування нової екологічної корпоративної бізнес-культури і бізнес-етики; по-третє, формування стійкого купівельного попиту на екобезпечні товари і послуги; по-четверте, орієнтації малих сільськогосподарських товаровиробників на ведення екологічно орієнтованого виробництва [4].

Екобезпечна продукція включає чотири рівні якості:

- висока якість основної корисності продуктів харчування - прийнятність до споживання, енергетична та біологічна цінність, смак, зовнішній вигляд;

- екологічна якість продукту в цілому - відсутність шкідливих речовин, його використання, вживання або споживання не шкодить здоров'ю, не має значної негативної дії на природне середовище;

- екологічна якість виробництва - мінімізація використання ресурсів та енергії, зниження виробничих викидів і відходів усіх видів;

- екологічна якість утилізації відходів - застосовується упаковка продуктів харчування, придатна до рециклювання (повторного використання) [10, с. 280].

Агропродовольча діяльність у даному напрямку повинна реалізовуватися через правовий, економічний, функціональний та інституційний механізми (рис. 1).

Правовий механізм включає в себе сукупність правових норм, що вміщені у відповідних законодавчих актах та нормативно-правових документах, які спрямовані на забезпечення реалізації агропродовольчої політики, а саме: Конституція України, Закон України «Про основи національної безпеки України», «Про прожитковий мінімум», «Про основні засади державної аграрної політики на період до 2015 року», «Про державну підтримку сільського господарства України», «Про зерно та ринок зерна в Україні», «Про молоко та молочні продукти, «Про 


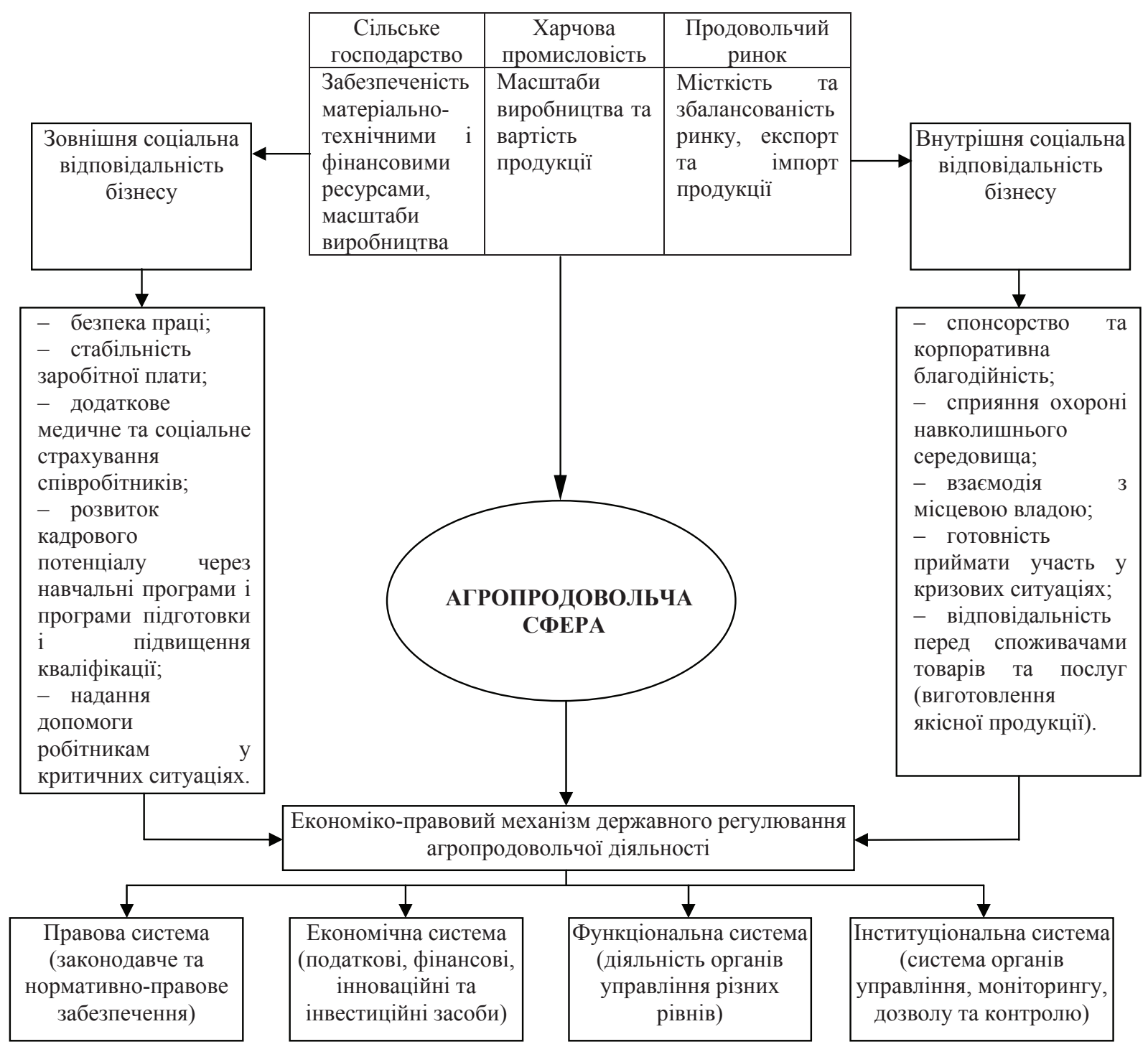

Рис. 1. Схема реалізації системи соціальної відповідальності бізнесу в агропродовольчій сфері* *Джерело : розроблено автором на основі [5, с. 72].

державний матеріальний резерв», «Про безпечність та якість харчових продуктів», «Про рибу, інші водні живі ресурси та харчову продукцію 3 них», «Про насіння та садибний матеріал», інші закони, міжнародні договори України, згода на обов'язковість яких надана Верховною Радою України, а також інші нормативно-правові акти.

Правовий механізм забезпечення діяльності агропродовольчої системи постійно удосконалюється, про що свідчать проекти законів, які надходять до Верховної Ради України, так, у 2011 р. на розгляд Верховної Ради подано два проекти законів «Про основи продовольчої безпеки України» (ВР реєстр № 8370 від 08.04.2011р.) та «Про продовольчу безпеку України» (ВР реєстр № 8370_1 від 28.04.2011р.), в яких визначається проблемність та необхідність формування високого рівня якості життя населення в частині забезпечення продуктами продовольства відповідно до науково-обгрунтованих фізіологічних потреб.

Економічний механізм являє собою сукупність економічних регуляторів, визначених законодавством i спрямованих на забезпечення ефективної діяльності агропродовольчої системи. До економічних регуляторів, що здійснюються державою, належать прогнозування, планування, програмування, регулювання зовнішньоекономічної діяльності, фінансування та кредитування, яке для агропродовольчої системи включає: цінове регулювання сільськогосподарської продукції, бюджетні дотації та позики, кредитні субсидії, митні збори тощо [5, с. 71].

Функціональний механізм включає в себе перелік завдань із формування та забезпечення реалізації агро- 
продовольчої функції держави, що виконуються органами державної влади у межах, встановлених актами чинного законодавства. До основних завдань реалізації функціонального механізму належать: прогнозування розвитку галузей агропродовольчого виробництва; техніко-технологічне переоснащення агропромислового виробництва; забезпечення підтримки підприємств, особистих селянських і фермерських господарств, сільськогосподарської кооперації; розробка і здійснення заходів щодо розвитку інфраструктури продовольчого ринку; використання та охорона земель усіх категорій та форм власності; контроль якості та безпечності сільськогосподарської продукції; розробка загальнодержавного балансу попиту і пропозиції основних видів сільськогосподарської продукції; регулювання зовнішньоекономічної діяльності суб'єктів агропродовольчого ринку та ін.

Інституційний механізм охоплює собою систему органів державної влади, регіонального та місцевого самоврядування, які прямо чи опосередковано беруть участь у реалізації державної агропродовольчої політики відповідно до покладених на них компетенцій. Головним органом у системі центральних органів виконавчої влади 3 питань формування та забезпечення аграрної політики є Міністерство аграрної політики та продовольства України (Мінагрополітики України).

Всі ці елементи становлять єдину систему, яка охоплюється поняттям «Економіко-правовий механізм державного регулювання агропродовольчої діяльності» і в якому втілюються як економічні регулятори, так i правові чинники. Економіко-правовий механізм державного регулювання агропродовольчої діяльності визначає цілеспрямованість, формальну визначеність, загальнообов'язковість, сприяє врегулюванню відносин в аграрній сфері, застосуванню превентивних, оперативних, стимулюючих заходів до юридичних та фізичних осіб в агропродовольчій системі. Він закономірно залежить від рівнів економічного, політичного, правового, соціального, культурного та технологічного розвитку суспільства [5, с. 72].
Важливу роль у функціонуванні суб'єктів агропродовольчої сфери у сучасних умовах відіграє зовнішня та внутрішня соціальна відповідальність бізнесу.

Халда Н.А. серед переваг впровадження соціальної відповідальності бізнесу виокремлює моральний обов'язок підприємницьких структур перед суспільством у забезпеченні соціального добробуту; сконцентровані на підприємствах людські та фінансові ресурси, що дозволяють вирішити ряд проблем за допомогою соціальної відповідальності бізнесу; формування позитивного іміджу підприємства у суспільстві та створення сприятливого середовища для подальшого розвитку підприємства.

До недоліків реалізації соціальної відповідальності відносить формування додаткових витрат на підприємстві, що мають спрямовуватись на відповідні проекти, зменшення чистого прибутку підприємства, що певним чином нівелює основний стимул розвитку підприємництва як такого, недостатній досвід підприємств у вирішенні соціальних проблем та необхідність ведення додаткової звітності [9, с. 329].

Висновки та перспективи подальших досліджень. Питання соціальної відповідальності все більше актуалізується у свідомості українського бізнесу, так як підприємства і корпорації є не тільки основою економічних відносин, але впливають на соціальні процеси, що протікають в сучасному суспільстві. Бізнес займає все більше місця в житті суспільства, виходить за рамки його професійної орієнтації. Він повинен вибудовувати відносини 3 безліччю взаємозалежних осіб, так як на його діяльність, крім внутрішнього середовища, впливає зовнішнє - влада, некомерційні організації, споживачі, 3МI, міжнародні організації та партнери, жителі території, на якій безпосередньо розташоване підприємство і т.д.

Отже, в умовах інтеграції України до європейського економічного простору необхідно більше уваги приділяти дослідженню розвитку соціально-економічних процесів, важливою складовою яких виступає соціальна відповідальність бізнесу.

\section{Література}

1. Власова Т. Р. Соціальна відповідальність бізнесу: сутність та тенденції / Т. Р. Власова // Вісник Чернівецького торговельноекономічного інституту. Економічні науки. - 2013. - Вип. 1. - С. 52-57.

2. Воронецька I. Розвиток екологічного маркетингу в контексті еколого-економічної безпеки агропродовольчого ринку [Електронний ресурс] / I. Воронецька. - Режим доступу : http://economics-of-nature.net/uploads/arhiv/2011/ Voronetska.pdf.

3. Зверева Т. В. Социальная ответственность как способ гармонизации интересов бизнеса и власти / Т. В. Зверева // Экономические и гуманитарные исследования регионов. - 2011. - № 4. - С. 86-93.

4. Катан Л. І. Напрями розвитку управління агропродовольчою системою України : еколого-економічний аспект / Л. I. Катан. [Електронний ресурс] - Режим доступу : http://library.kpi.kharkov.ua/Vestnik/2010_8/stati/Katan. pdf.

5. Княженко I. I. Агропродовольча функція держави в системі регулювання соціально-економічних процесів / I. I. Княженко // Вісник Бердянського університету менеджменту і бізнесу. - 2011. - № 4 (16). - С. 67-73.

6. Піроженко Н. Феномен соціальної відповідальності бізнесу: теоретичний та історичний аспекти / Н. Піроженко. [Електронний ресурс] - Режим доступу : http://www.nbuv.gov.ua/portal/Soc_gum/Apdu_o/2009_1/ R_2/Pirogenko.pdf. 
7. Проект Закону України «Про продовольчу безпеку України» / Портал Ліга : закон. [Електронний ресурс] - Режим доступу : http://search.ligazakon.ua/1_doc2.nsf/link1/JF6GI01A.html.

8. Соціальна відповідальність бізнесу: розуміння та впровадження [Електронний ресурс]. - Режим доступу : http://www. un.org.ua/files/ Concept Paper.pdf.

9. Х Халда Н. О. Соціальна відповідальність бізнесу як складова людського розвитку в Україні та світі / Н. О. Халда // Наука й економіка. - 2013. - т. 2, Вип. 4. - С. 326-332.

10. Хромушина Л. А. Екологізація сільського господарства як основа еколого-економічної безпеки / Л. А. Хромушина // Вiсник СНАУ. - 2008. - № 1. - С. 278-283.

11. Юрчишин В. В. Фундаментальність як базова основа вчення академіка І. І. Лукінова в царині аграрної економіки. Теоретичні надбання академіка I. І. Лукінова та їх значення у розвитку аграрного виробництва України : зб. виступів 10 жовт. 2008 р. $/$ В. В. Юрчишин; відп. за вип. Г. М. Підлесецький. - К. : ННЦ ІАЕ, 2009. - С. 44-56.

12. Milton Friedman: The Social Responsibility of Business Is to Increase Its Profits /New York Times Magazine, September 13, 1970, pp. 32-33.

Стаття надійшла 10.07.2014

Рецензент: Музиченко Анатолій Степанович, доктор економічних наук, професор, завідувач кафедри економіки підприємства, фінансів, обліку та аудиту Уманського державного педагогічного університету імені Павла Тичини

\title{
Стойка В.А.
}

кандидат экономических наук кафедра экономической теории и права E-mail:vet_ua2@mail.ru

Уманский государственный педагогический университет имени Павла Тычины ул. Садовая, 2, г. Умань, Черкасская обл., Украина, 20300

\section{СОЦИАЛЬНАЯ ОТВЕТСТВЕННОСТЬ БИЗНЕСА - ВАЖНАЯ СОСТАВЛЯЮЩАЯ АГРОПРОДОВОЛЬСТВЕННОГО РЫНКА}

В статье рассмотрены отдельные аспекты формирования социальной ответственности предприятий агропродовольственной сферы, их участия в социальном развитии городов, регионов и страны в целом, определены условия для расширения практики социальной ответственности бизнеса. Предложена схема реализации системы социальной ответственности бизнеса в агропродовольственной сфере.

Ключевые слова: агропродовольственная сфера, социальная ответственность бизнеса, экологическая ответственность, эколого-экономическая безопасность, конкурентные преимущества, устойчивое развитие, стратегия.

\author{
Stoyka V.0. \\ $\mathrm{PhD}$ in Economics \\ Department of Economics and Law \\ E-mail:vet ua2@mail.ru \\ Sadova Street, 2, Uman, Cherkasy region, Ukraine, 20300
}

Uman State Pedagogical University named after Paul Tychyna

\section{BUSINESS SOCIAL RESPONSIBILITY - AN IMPORTANT PART OF AGRI-FOOD MARKETS}

Abstract. The paper outlines the main parameters of the social responsibility of business in the present conditions of the market economy.

The analysis of the different scientific approaches, which studied the evolution of the social responsibility of business in society, the agricultural business in the current economic conditions, the development of depressed rural areas, the formation of ecological and economic security in the agricultural sector, the benefits of implementing business social responsibility in agri-food industry, has been done.

The main directions of the social responsibility of small, medium and large scale business enterprises have been defined.

The study characterizes main types and areas of the business social responsibility.

Some aspects of the business social responsibility formations in agri-food sector have been studied.

The research highlights the scheme of implementation of business social responsibility in the agri-food sector, where internal and external corporate social responsibility plays the major role.

Keywords: agri-food sector, business social responsibility, ecological responsibility, ecological-economic security, competitive advantage, sustainable development, strategy. 


\section{References}

1. Vlasova T. R. (2013). Sotsialna vidpovidalnist biznesu: sutnist ta tendentsii. Visnyk Chernivetskoho torhovelno-ekonomichnoho instytutu. Ekonomichni nauky, 1, 52-57.

2. Voronetska I. Rozvytok ekolohichnoho marketynhu v konteksti ekoloho-ekonomichnoi bezpeky ahroprodovolchoho rynku. [Elektronnyi resurs]. Rezhym dostupu : http://economics-of-nature.net/uploads/arhiv/2011/Voronetska.pdf.

3. Zvereva T. V. (2011). Sotsyalnaia otvetstvennost kak sposob harmonyzatsii interesov biznesa i vlasti. Ekonomicheskie i humanitarnie issledovaniya rehionov, 4, 86-93.

4. Katan L. I. Napriamy rozvytku upravlinnia ahroprodovolchoiu systemoiu Ukrainy : ekoloho-ekonomichnyi aspekt. [Elektronnyi resurs]. Rezhym dostupu : http://library.kpi.kharkov.ua/Vestnik/2010_8/ stati/Katan.pdf.

5. Kniazhenko I. I. (2011). Ahroprodovolcha funktsiia derzhavy v systemi rehuliuvannia sotsialno-ekonomichnykh protsesiv. Visnyk Berdianskoho universytetu menedzhmentu i biznesu, 4 (16), 67-73.

6. Pirozhenko N. Fenomen sotsial'noi vidpovidal'nosti biznesu : teoretychnyi ta istorychnyi aspekty. [Elektronnyi resurs]. Rezhym dostupu: http://www.nbuv.gov.ua/portal/Soc_gum/Apdu_o/2009_1/ R_2/Pirogenko.pdf.

7. Proekt Zakonu Ukrainy «Pro prodovol'chu bezpeku Ukrainy». [Elektronnyi resurs]. Portal Liha: zakon. Rezhym dostupu: http:// search.ligazakon.ua/1_doc2.nsf/link1/JF6GI01A.html.

8. Sotsial'na vidpovidal'nist' biznesu: rozuminnia ta vprovadzhennia. [Elektronnyi resurs]. Rezhym dostupu: http://www.un.org. ua/files/Concept_Paper.pdf.

9. Khalda N. O. (2013). Sotsial'na vidpovidal'nist' biznesu yak skladova liuds'koho rozvytku v Ukraini ta sviti. Nauka i ekonomika, Vol. 2, 4, 326-332.

10. Khromushyna L. A. (2008). Ekolohizatsiia sil's'koho hospodarstva yak osnova ekoloho-ekonomichnoi bezpeky. Visnyk SNAU, $1,278-283$

11. Iurchyshyn V. V. (2009). Fundamental'nist' yak bazova osnova vchennia akademika I. I. Lukinova v tsaryni ahrarnoi ekonomiky. Teoretychni nadbannia akademika I. I. Lukinova ta yikh znachennia u rozvytku ahrarnoho vyrobnytstva Ukrainy: zb. vystupiv 10 zhovt. 2008 r. K.: NNTs IAE, 44-56.

12. Milton Friedman: The Social Responsibility of Business Is to Increase Its Profits. New York Times Magazine, September 13, $1970,32-33$. 